4. Аналіз судової практики у справах про відшкодування моральної шкоди, завданої у зв'язку з ушкодженням здоров'я під час виконання трудових обов'язків: Лист Вищого спеціалізованого суду України з розгляду цивільних та кримінальних справ від 1 вересня 2011 року. URL: http://zakon4.rada.gov.ua/ laws/show/n0010740-11 (дата звернення: 20.11.2018).

5. Judgment Holm v. Sweden (Application no. 14191/88) [Electronic resource] / Judgment Holm v. Sweden. 1993. 25 November. URL: http://hudoc.echr.coe.int/ eng?i=001-57851 (дата звернення: 21.11.2018).

6. Ухвала Верховного Суду України від 29 вересня 2010 року по справі № 6-1989св08. URL: http://reyestr.court.gov.ua/Review/11641921 (дата звернення: 14.12.2018).

7. Рішення по Справі «Сірик проти України» (Заява № 6428/07) від 31 березня 2011 року. URL: http://zakon4.rada.gov.ua/laws/show/974_939 (дата звернення: 05.12.2018).

8. Рішення по Справі «Українська Прес-Група проти України» (Заява № 72713/01) від 29 березня 2005 року. URL: http://zakon4.rada.gov.ua/ laws/show/980_382 (дата звернення: 05.12.2018).

9. Рішення Верховного Суду України від 16 червня 2010 року по справі № 6-11324св09. URL: http://reyestr.court.gov.ua/Review/10120963 (дата звернення: 06.12.2018).

10. Рішення Верховного Суду України від 3 лютого 2010 року по справі № 6-17172св07. URL: http://reyestr.court.gov.ua/Review/8038793; Рішення Верховного Суду України від 6 травня 2010 року по справі № 6-2090сво10. URL: http://reyestr.court.gov.ua/Review/10132697 (дата звернення: 06.12.2018).

\title{
Kot O. Peculiarities of personal and other non-property rights protection
}

This article is dedicated to the analysis of personal and other non-property rights protection specifics. The most prominent sources were analysed. Actual court practice was introduced, including Europan Cort of Human Rights judgements. The author offers possible solutions for the existing practical issues.

Keywords: personal and other non-property rights, protection of subjective civil rights, personal nonproperty relationship, court practice.

\section{ПРОБЛЕМИ ЗАБЕЗПЕЧЕННЯ ЗЕМЕЛЬНИХ ПРАВ В УМОВАХ РЕГІОНАЛЬНОЇ НЕСТАБІЛЬНОСТІ}

https://doi.org/10.32849/2409-9201.2018.18.14

Лапечук П. І.,

стариий науковий співробітник НДІ приватного права і підприємнищтва імені академіка Ф. Г. Бурчака НАПрН України

Попович Т. Г.,

науковий співробітник НДІ приватного права і підприємництва імені академіка Ф. Г. Бурчака НАПрН України

Здійснено аналіз відносин власності на земельні ресурси в Україні за період проведення антитерористичної операчії та на тлі падіння економіки в Україні. Подаються пропозииї стосовно умов та можсливостей запуску ринку земель сільськогосподарського призначення, мораторій на відчуження яких діє до 01.01.2018.

Ключові слова: мораторій на продаж земель сільськогосподарського призначення, ринок земель, відчуження земель, земельні відносини періоду нестабільності.

За інформацією Держгеокадастру Україна володіє значним земельним потенціалом, який становить 5,7\% території Європи, а із 60,3 млн гектарів майже 70 \% становлять сільськогосподарські угіддя 3 високою родючістю [1]. Такий потенціал може розглядатися як потужна конкурентна перевага України, проте його практична реалізація вимагає впровадження ефективної моделі земельних відносин, адекватної сучасним жорстким умовам міжнародної конкуренції. В умовах глобальної економіки та дедалі більшої інтеграції України у світові економічні процеси саме агропромисловий комплекс може стати авангардом розвитку української економіки.

Метою статті $\epsilon$ аналіз земельного законодавства, що регулює відносини користування та розпорядження землями сільськогосподарського призначення, а також виклад пропозицій щодо умов створення та функціонування ринку земель i скасування мораторію на відчуження земель сільськогосподарського призначення.

На сьогодні відповідно до п. 15 розділу X «Перехідні положення «Земельного кодексу України» до 1 січня 2018 р. діє мораторій на купівлю-продаж сільськогосподарських земель, умовою зняття якого $\epsilon$ набрання чинності Закону України «Про обіг земель сільськогосподарського призначення» [2].

У грудні 2016 р. відбулися парламентські слухання на тему «Регулювання обігу земель сільськогосподарського призначення: пошук української моделі». На слуханнях було констатовано, що поступово формуються передумови для запровадження ринкового обігу земель та вторинного 
ринку земельних ділянок сільськогосподарського призначення, але ще рано говорити про відкриття цього ринку. Це питання поступово перейшло з економічної площини в політичну, загострюючи тим самим соціальну напругу в суспільстві (особливо серед сільських жителів), породжуючи політичні спекуляції навколо земельних питань та провокуючи створення тіньових схем щодо відчуження земельних ділянок.

На парламентських слуханнях обговорювалися невирішені питання, що знецінюють вже проведені реформи, зокрема щодо:

1) децентралізації повноважень $з$ розпорядження землями сільськогосподарського призначення, які знаходяться за межами населених пунктів, сільським, селищним та міським радам (об'єднаним територіальним громадам);

2) неможливості залучення кредитів під заставу прав власності й користування сільськогосподарськими землями;

3) інформації про інвентаризацію земель сільськогосподарського призначення, у тому числі за формами власності та суб'єктами господарювання;

4) низької інвестиційної привабливості землекористування;

5) здійснення землеустрою, раціонального використання та охорони земель сільськогосподарського призначення, збереження та відновлення родючості грунтів;

6) введення земель сільськогосподарського призначення в економічний обіг, на основі якого мають напрацьовуватися відповідні нормативно-правові акти 3 даного питання, у тому числі регуляторного характеру;

7) використання нерозподілених та невитребуваних земельних ділянок і земельних часток (паїв), земель колективної власності, консолідації земель, обміну земельними ділянками;

8) процедур економічного стимулювання раціонального використання та охорони земель, збереження, відтворення і підвищення родючості грунтів.

Як заявив Прем’єр-міністр України, затвердження Верховною Радою закону про обіг земель сільськогосподарського призначення очікується до кінця травня 2017 р., що дозволить діючому мораторію на продаж земель сільськогосподарського призначення втратити силу 3 кінця 2017 р. [3]. Уряд веде мову про те, що ми можемо створити модель ринку землі, яка буде дозволяти тільки фізичним особам - українцям між собою продавати землю, яка їм належить.

Розглянувши публікації в пресі, виступи громадських діячів, політиків та спеціалістів у сфері земельного права, ми сформували такі основні аргументи стосовно зняття мораторію на продаж земель сільськогосподарського призначення:

1) за:

- агресивна війна Росії проти України, а тому треба відновлювати країну шляхом розвитку агарного сектора;

- селяни отримають гроші, а землі будуть використовуватися за призначенням;

- МВФ надасть кредитування Україні;

- не буде порушуватися право на розпорядження власністю, тобто не буде прихованих угод продажу цих земель;

2) проти

- війна Росії проти України не сприятиме формуванню справедливої ціни на землі;

- бідність селян спричинить тотальний перехід земель до латифундистів - резидентів чи нерезидентів України;

- у малих та середніх підприємців аграрного сектору (фермерів) немає грошей на викуп земель;

- немає доступної інформації про варіанти використання землі нинішніми власниками;

- земля є основою національної безпеки України та може перебувати у власності лише громадян України.

Конституційними засадами реалізації права власності на землю в Україні є те, що земля є власністю народу України, а розпорядником земель є держава. У той же час не заперечується право приватної власності, але це право є обмеженим. 3 іншого боку - земельні ресурси є основою національної безпеки України, а закони (їх зміст) мають відповідати Конституції України.

Землі сільськогосподарського призначення зазвичай відносяться до особливо цінних земель, правовий статус яких визначається ст. 150 Земельного кодексу України. До них, зокрема, відносяться чорноземи нееродовані несолонцюваті на лесових породах; лучно-чорноземні незасолені несолонцюваті суглинкові грунти; темно-сірі опідзолені грунти та чорноземи опідзолені на лесах і глеюваті; бурі гірсько-лісові та дерново-буроземні глибокі і середньо глибокі грунти; дерново-підзолисті суглинкові грунти; коричневі грунти Південного узбережжя Криму, дернові глибокі грунти Закарпаття.

Крім розпайованих та переданих у власність земель сільськогосподарського призначення, у цій категорії земель є землі, що перебувають у постійному користуванні. Сьогодні вони використовуються комунальними та державними підприємствами, установами та організаціями. Для них закріплено 
обов'язок цільового використання земель та дозволяється субкористування іншими суб'єктами. Держава та іiї повноважні органи фактично не здійснюють контроль за такими землями, хоча існує обмеження загальної площі с/г земель до 100 гектарів (площа може бути збільшена у разі успадкування земельних ділянок за законом).

Для вирішення питання безвідповідального ставлення до земель сільськогосподарського призначення нами пропонується надавати їх комунальним та державним підприємствам, установам та організаціям лише у строкове користування, а нецільове їх використання має автоматично спричиняти припинення прав. Ще одним запобіжником може стати заборона субвикористання, у тому числі без внесення до державних реєстрів. Для зміни цільового призначення сільськогосподарських земель слід ввести додаткову процедуру проведення громадського обговорення (слухань). Для зниження ризиків зловживання правами слід встановити чітке граничне обмеження загальної площі с/г земель до 100 гектарів, а збільшення площі у разі успадкування необхідно виключити.

Доцільним $є$ на первинному етапі застосовувати процедури викупу земель у державний банк земель. Оскільки усі землі України $є$ власністю народу України, то банк земель має називатися народним 3 відповідними наглядовими органами від громадських організацій. Оренда земель сільськогосподарського призначення 3 народного земельного банку України має здійснюватися за результатами проведення аукціону відповідно до законодавства України (ч. 1 ст. 135 Земельного кодексу України - земельні торги проводяться у формі аукціону, абз. 3 ч. 3 ст. 135 Земельного кодексу України - учасником земельних торгів $є$ фізична або юридична особа, яка подала виконавцю земельних торгів документи, зазначені в ч. 7 ст. 137 Земельного кодексу України, сплатила реєстраційний та гарантійний внески, зареєстрована у книзі реєстрації учасників земельних торгів і відповідно до закону може набувати право власності чи користування земельною ділянкою, яка виставляється на земельні торги).

Суб’єктів слід також ретельно перевіряти на наявність у фізичної особи сільськогосподарської освіти або у юридичної - кваліфікованих працівників з такою ж освітою. Особа має довести, що має можливість обробляти землю (перспективний план використання земель + засоби + методи). Права таких орендарів мають бути суттєво обмежені:

- заборона суборенди (субкористування);

- лише цільове використання земель;

- дострокове автоматичне припинення прав за умови виявлення відхилення від умов користування.

На сьогодні вже існують деякі законодавчі основи таких обмежень:

1) у ч. 1 ст. 110 Земельного кодексу України на використання власником земельної ділянки або ії частини може бути встановлено обмеження;

2) п. «а» ч. 1 ст. 96 Земельного кодексу України передбачає обов'язок використання землі за цільовим призначенням.

Таким чином, ми можемо дійти висновку, що для запуску ринку земель, на які до 01.01.2018 накладено мораторій на відчуження, необхідні такі законодавчо закріплені умови.

1. Юридичні особи та інші суб'єкти, що не відносяться до громадян України, можуть лише користуватися землями сільськогосподарського призначення.

2. Оренда чи право користування землями сільськогосподарського призначення надається лише на конкурсних засадах.

3. Швидке та ретельне проведення інвентаризації земель сільськогосподарського призначення.

4. Створення відкритого реєстру користувачів землями сільськогосподарського призначення.

5. Проведення ліквідації інформаційної безграмотності селян (обов’язок покласти на місцеві ради).

6. Забезпечення реального раціонального використання земель сільськогосподарського призначення 3 контролем за дотриманням вимог.

7. Надання компенсацій ефективним землекористувачам.

8. Надання державних гарантій національним суб'єктам сільськогосподарської сфери.

9. Передбачення викуп державою земель сільськогосподарського призначення у разі:

- бажання власника (фізичної чи юридичної особи);

- у разі невикористання за призначенням протягом 4-х років або закінчення планових сівозмін;

- закладених (заставних) земель сільськогосподарського призначення;

- входження земель сільськогосподарського призначення до складу відумерлої спадщини (викуп у громади).

\section{СПИСОК ВИКОРИСТАНОЇ ЛІТЕРАТУРИ:}

1. Ринок земель. URL: http://land.gov.ua/icat/rynok-zemel/ (дата звернення: 11.11.2017).

2. Земельний кодекс України від 25.10.2001 № 2768-III. Інформаційно-пошукова система База даних «Законодавство». Версія 2.9.0. («Назва з екрану»). 
3. Меморандум між МВФ та Україною від 02.03.2017. URL: https://www.minfin.gov.ua/uploads/ redactor/filesМеморандум\%20МВФ_Київ,\%202\%20березня\%202017.pdf (дата звернення: 11.11.2017).

Lapechuk P., Popovych T. Problems of providing land rights in the conditions of regional instability

The analysis of property relations on land in Ukraine during the counterterrorist operation and against the background of economic decline in Ukraine. Served proposal regarding the conditions and opportunities for launching agricultural land market moratorium on the alienation which is valid until 01.01.2018.

Keywords: moratorium on the sale of agricultural land, land market, alienation of land, land relations of the period of instability.

\section{ДО ПИТАННЯ ПОСИЛЕННЯ ЗАХИСТУ ПРАВ ДИТИНИ НА УТРИМАННЯ}

\section{Левківський Б. К.,}

https://doi.org/10.32849/2409-9201.2018.18.15

кандидат юридичних наук, провідний науковий співробітник відділу юрисдикційних форм правового захисту суб' єктів приватного права, судоустрою та судочинства НДІ приватного права і підприємництва імені академіка Ф. Г. Бурчака НАПрН України

У статті проаналізовано норми міжнародного та вітчизняного законодавства, якими регламентовано права дитини, а також механізми забезпечення здійснення цих прав та їх юрисдикційний захист від будь-яких дій, спрямованих на порушення прав та інтересів дитини.

Ключові слова: відповідальність батьків, обмеження батьківських прав, аліменти, право на виїзд за межі України, юрисдикційний захист.

Проблематика закріплення, а ще більше гарантії реалізації та захисту прав дитини є найактуальнішою тематикою досліджень в сучасній юридичній науці. Кожен науковець за різних часів, досліджуючи цю проблематику, пропонував свої шляхи iï вирішення. Навіть ті науковці, які мали або нині мають наукові інтереси в інших площинах, досліджували проблематику прав дитини. I це зрозуміло, адже дитина - це майбутнє, від якого залежить людство. А відтак, від того, які ми - сучасне людство зможемо створити належні умови для виховання дитини, для іiі якісного життя, забезпечення досягнення iï інтересів, зможемо забезпечити й існування людства. Саме тому юристи-науковці дедалі частіше замислюються над тим, в якому якісному стані на сьогодні перебувають норми законодавства, що закріплюють права дитини, і як ці права відповідають ії інтересам, чи можуть сучасні норми права забезпечити дитині досягнення іiі інтересів, захистити ії̈ за допомогою цих норм.

Результати правового аналізу існуючих норм чинного сімейного законодавства України, наукової літератури, присвяченої цій тематиці, дають право стверджувати, що на сучасному етапі розвитку спеціального законодавства України ми не здійснили всіх необхідних заходів, спрямованих на створення нормативно-правової бази якісно нового рівня, яка повною мірою відповідатиме сучасним світовим тенденціям у сфері захисту прав дитини, сприятиме інтересам самої дитини. На жаль, ми і досі не розглядаємо дитину як повноцінного партнера, як людину, яка повною мірою наділена правами, як вільну людину зі своїми інтересами, яка в силу своїх фізіологічних особливостей потребує від нас допомоги у соціалізації, а не підкорення нашій волі, яка іноді настільки егоїстична, що прямо протирічить інтересам дитини.

Судова практика, яка на сьогодні існує в Україні, дивним чином ігнорує права дитини. Навіть ті поодинокі норми, які закріплюють права дитини на свободу, судовою практикою нівелюються.

Таким прикрим непорозумінням $є$ практика судів в Україні, яка сформувалася відповідно до правової позиції Верховного Суду України (далі - ВСУ), що на сьогодні реформується. Так, як не дивно, саме ВСУ долучився до порушення прав дитини, фактично створивши ситуацію, за якої тисячі дітей стали заручниками настрою окремих батьків. На підтвердження даної тези достатньо згадати ганебні правові висновки, які фактично порушують права дитини, ігнорують міжнародні принципи, міжнародні нормативні акти та, врешті-решт, здоровий глузд. Підтвердженням практики ВСУ можна навести ті правові позиції, які в сучасному світі, в практиці Європейського Суду з прав людини викликають занепокоєння щодо нашої судової гілки влади, щодо іiі можливості ефективно здійснювати свої функції - правосуддя.

Одним 3 найбільш ганебних правових висновків $є$ висновок ВСУ у справі 6-2445цс16, в якій прямо проігноровано право дитини, право, яке закріплено як Конвенцією про права дитини, так і чинним СК України, ЦПК України - право вільно висловлювати погляди з усіх питань, що торкаються дитини. При чому в Конвенції про права дитини зазначено, що власним думкам дитини приділяється належна увага згідно з іiі віком і зрілістю (ст. 21 Конвенції про права дитини). Відповідно ще до 